\title{
Etika Pergaulan Islami Santri Madrasah Aliyah (MA) di Pesantren Jabal Nur Kecamatan Kandis Kabupaten Siak
}

\author{
M. YUSUF AHMAD* \\ SYAHRAINI TAMBAK** \\ MIRA SAFITRI***
}

\author{
*Fakultas Agama Islam (FAI) Universitas Islam Riau (UIR) \\ Jl. Kaharuddin Nasution No.113 Perhentian Marpoyan Pekanbaru 28284 \\ Hp: 081365542760 \\ **Fakultas Agama Islam (FAI) Universitas Islam Riau (UIR) Pekanbaru \\ Jl. Kaharuddin Nasution, No. 113, Perhentian Marpoyan Pekanbaru 28284 \\ e-mail: syahraini tambak@yahoo.co.id \\ ***Fakultas Agama Islam (FAI) Universitas Islam Riau (UIR) \\ Jl. Kaharuddin Nasution No.113 Perhentian Marpoyan Pekanbaru 28284
}

\begin{abstract}
Abstrak: Islam telah mengatur etika pergaulan remaja, perilaku tersebut merupakan batasan-batasan yang dilandasi nilai-nilai agama. Oleh karena itu perilaku tersebut harus diperhatikan, dipelihara dan dilaksanakan oleh para remaja. Berdasarkan studi permasalahan di Pesantren Jabal Nur Kecamatan Kandis Kabupaten Siak di temukan beberapa gejala sebagai berikut: (1) Ada sebagian para santri/santriwati dalam proses pergaulan yang masih berbicara yang kurang sopan kepada teman sebaya; (2) Ada sebagian para santri/santriwati kurang menghormati guru, hal ini bisa dilihat ketika bertemu mereka tidak menegur atau menyapa guru yang dijumpainya; (3) Ada sebagian didalam pergaulan antara santri dan santriwati tidak menjaga pandangannya terhadap sesama lawan jenis, yang akibatnya akan membawa dampak menimbulkan nafsu; (4) Ada sebagian dalam pergaulan antara santri dan santriwati saling membenci dan iri yang mengakibatkan antara mereka saling bermusuhan. Untuk mengetahui situasi yang lebih jelas terkait etika pergaulan remaja pada para santri/santriwati di Pesantren Jabar Nur Kecamatan Kandis Kabupaten Siak, maka penulis melakukan penelitian terkait etika pergaulan ini. Jenis penelitian ini adalah Deskriptif kuantitatif, penelitian ini berlokasi di Pesantren Jabal Nur Kecamatan Kandis Kabupaten Siak selama 4 bulan. Populasinya berjumlah 350 orang sedangkan sampelnya berjumlah 86 orang. Data primer yang dikumpulkan menggunakan angket, sedangkan data skunder berupa dokumentasi yang berhubungan dengan penelitian. Teknik pengolahan data dengan melakukan editing, skoring, dan tabulating. Berdasarkan analisis data peneliti memperoleh hasil penelitian $84,35 \%$ berada pada rentang 81-100\%. Ini menggambarkan bahwa etika pergaulan Islami santri Madrasah Aliyah (MA) Pesantren Jabal Nur Kecamatan Kandis Kabupaten Siak pada kategori "Baik”.
\end{abstract}

\section{PENDAHULUAN}

Berbicara tentang remaja atau masa muda berarti membicarakan tentang diri sendiri, hal ini sering didapati dalam banyak artikel (tulisan), bahkan masyarakat, orang tua, guru sering menyaksikan peran dan partisipasi remaja dan pemuda yang

Jurnal Al-hikmah Vol. 13, No. 2, Oktober 2016 ISSN 1412-5382 
besar dalam membangun, menyumbang, dan mendukung perkembangan bangsa.

Sebagaimana yang telah diketahui bahwa agama Islam menganjurkan agar anak didik menjadi seorang remaja muslim yang beretika, berakhlaqul karimah, dan dapat menjadi seorang pemimpin yang fleksibel (tidak kaku/bisa menyesuaikan) bagi masyarakat di masa yang akan dating karena setiap orang pasti akan menjadi seorang pemimpin.

Menurut Anirah dan Hasnah (2013:285), mengungkapkan bahwa saat ini kesan yang ada dalam benak masyarakat tentang perilaku remaja justru cenderung kebanyakan negatif. Dimulai dari perkelahian antar pelajar, pornografi, kebut-kebutan, tindakan kriminal seperti pencurian, dan perampasan barang orang lain, pengedaran obat-obat terlarang dan bahkan yang lebih heboh adalah dampak pergaulan bebas yang semakin mengkhawatirkan. Dengan demikian manusia akan mudah terjerumus keberbagai penyelewengan dan kerusakan akhlak dengan melakukan perampasan hak orang lain, pelecehan seksual, pembunuhan, dan timbulah persaingan tidak sehat demi untuk mendapatkan apa yang diinginkan.

Kemerosotan moral remaja saat ini banyak dipengaruhi oleh terpaan media informasi di abad millennium semakin merambah dengan cepat. Di daerah terpencil sekalipun terdapat tempat penyewaan VCD dan pemutaran filmfilm porno, belum lagi media cetak yang demikian bebas mengumbar informasi seksual yang semakin mempengaruhi remaja untuk melakukan hal-hal yang bertentangan dengan ajaran agama (Anirah dan Hasnah, 2013:285).

Lebih lanjut Andi Anirah dan Sitti Hasnah, bahwa salah satu masalah yang perlu mendapat perhatian serius adalah bebasnya hubungan antar jenis di antara remaja (pemuda) yang menjadi tonggak pembaharuan. Pergaulan remaja diidentikkan dengan sekumpulan anak yang membentuk suatu kelompok (geng) dengan peraturan-peraturan tertentu yang beragam, dan tidak sedikit dari remaja yang salah dalam memilih pergaulan. Akibat dari salah memilih pergaulan diantaranya perlakuan yang semakin brutal, menggunakan barangbarang terlarang, semakin jauh dari orang tua, sering membolos saat sekolah dan sebagainya. Islam telah mengatur etika pergaulan remaja. Prilaku tersebut merupakan batasan-batasan yang dilandasi nilai-nilai agama. Oleh karena itu prilaku atau etika pergaulan tersebut harus diperhatikan, dipelihara, dan dilaksanakan oleh para remaja (Anirah dan Hasnah, 2013:258).

Menurut Suyono dkk, pembinaan generasi muda dapat dipandang penting jika semua orang menyadari kondisi sekarang tentang meningkatnya kenakalan remaja akhir-akhir ini. Masalah kenakalan remaja ini mengkhawatirkan berbagai pihak, antara lain orangtua, masyarakat dan pemerintah yang berkepentingan terhadap keberhasilan penbangunan Nasional. Kenakalan remaja adalah perilaku menyimpang dan dapat menimbulkan kerugian-kerugian baik pada diri anak remaja, keluarga dan masyarakat (Suyono dkk, 2014:43).

Menurut Andi Anirah dan Sitti Hasanah, Islam telah mengatur etika pergaulan remaja perilaku tersebut merupakan batasan-batasan yang dilandasi nilai-nilai agama. Oleh karena itu perilaku tersebut harus diperhatikan, dipelihara dan dilaksanakan oleh para remaja. Perilaku yang menjadi batasan dalam pergaulan adalah: (1) Menutup Aurat, Islam telah mewajibkan perempuan untuk menutup aurat demi menjaga kehormatan diri dan kebersihan hati. (2) Menjauhi Perbuatan Zina, Islam adalah agama yang menjaga kesucian. Dalam al-Qur'an Allah 
berfirman dalam surat al-Isra' ayat 32 yang artinya. "Dan janganlah kamu mendekati zina; (zina) itu sungguh suatu perbuatan yang keji dan suatu jalan yang buruk" ( Anirah dan Hasnah, 2013:292).

Kemudian menurut Abubakar Muhammad, islam mengasumsikan etika bergaul antara pria dan wanita menurut syariat islam yaitu, pria dan wanita dapat menjaga dan mengendalikan pandangan matanya dan memelihara nafsu seksualnya. Larangan berduaan sepasang muda-mudi tanpa disertai mahramnya. Kemudian pengaturan shaf laki-laki dan perempuan dalam shalat berjama'ah, adalah termasuk usaha pencegahan dari kemungkinan akibat jelek bagi kedua belah pihak dan rusaknya shalat itu sendiri (Muhammad, 1994:128).

\section{Fenomena}

mengkhawatirkan

ini sangat

bila terjadi di

Pesantren Jabal Nur Kandis Siak, namun berdasarkan observasi penulis melihat ada gejala yang terjadi seperti kurang nya bersikap sopan santun, berbicara kotor. Berbicara dengan perkataan yang baik, dalam proses pergaulan sejatinya, para santri di pesantren Jabal Nur Kandis Siak berbicara dengan sesama menggunakan perkataan yang baik. Sebab berbicara dengan perkataan yang baik mengandung pahala bagi orang yang melaksanakannya. Idealnya santrisantriwati di sana pergaulan yang islami dimana dalam pergaulan antar lawan jenis menundukkan pandangan (mengendalikan atau membatasi). Lakilaki dan perempuan sejatinya dalam proses pergaulan sehari-hari menjaga pandangan mata, dan tidak menimbulkan hawa nafsu. Di samping itu santri-santriwati, sejatinya dalam proses pergaulan mengajak berbuat untuk kebaikan, karena pergaulan yang baik akan mendatangkan kebaikan antar sesama. Santri dalam proses pergaulan dituntut untuk mengisi waktu luang dengan kegiatan yang bermanfaat, namun kenyataanya ada diantara para santri/santriwati di pesantren Jabal Nur Kandis Siak dalam proses pergaulan tidaklah seperti yang dikemukakan di atas.

Berdasarkan gejala-gejala yang di temukan di atas dari fenomena inilah penulis tertarik untuk melakukan penelitian, dalam hal ini seharusnya santri/santriwati di pesantren Jabal Nur Kandis Siak harus memiliki etika pergaulan yang baik yang sesuai dengan ajaran islam agar santri/santriwati tidak memiliki etika pergaulan yang bertentangan dengan ajaran Islam. Tapi kenyataanya sebagian dari santri/santriwati di pesantren Jabal Nur Kandis Siak belum menerapkan etika pergaulan yang diajarkan dalam Islam dengan baik.

\section{METODE}

Mengingat banyaknya permasalahan yang dicangkup oleh judul serta terbatasnya waktu, biaya, dan tenaga yang dimiliki, maka permasalahan dalam penelitian ini dibatasi pada "Etika Pergaulan Islami Santri Madrasah Aliyah (MA) di Pesantren Jabal Nur Kecamatan Kandis Kabupaten Siak".

Berdasarkan latar belakang masalah yang dikemukakan di atas, maka yang menjadi rumusan masalah dalam penelitian ini, adalah Bagaimanakah etika pergaulan Islami santri Madrasah Aliyah (MA) di Pesantren Jabal Nur Kecamatan Kandis Kabupaten Siak?

Adapun tujuan penelitian ini adalah untuk mengetahui etika pergaulan yang Islami pada santri Madrasah Aliyah (MA) Pesantren Jabal Nur Kecamatan Kandis Kabupaten Siak. Sedangkan manfaat yang di harapkan dari penelitian ini adalah: (a) Tujuan Teoritis. Penelitian ini diharapkan dapat menambah wawasan ilmu pengetahuan bagi penulis tentang etika bergaul Islami bagi peserta didik 
dalam pergaulan dan dapat digunakan sebagai bahan acuan di bidang penelitian yang sejenis; (b) Tujuan Praktis. Bagi guru Bagi guru sebagai informasi, diharapkan dapat membina muridnya untuk bisa menerapkan pergaulan yang islami yang telah di syariatkan dalam islam. Agar muridmurid menjadi muslim dan muslimah yang sejati; dan (c) Bagi peneliti lain. Sebagai bahan referensi dalam pembuatan karya ilmiah dengan judul yang sama.

\section{KONSEP TEORI}

\section{Hakikat Etika, Moral dan Akhlak Etika}

Menelusuri asal usul etika tidak lepas dari asli kata ethos dalam bahasa Yunani yang berarti kebiasaan (custom) atau karakter (character). Secara terminologis arti kata etika sangat dekat pengertiannya dengan istilah Al-Qur'an al-khuluq (Badroen dkk, 2007:4-7).

Dalam konteks filsafat, istilah etika berasal dari bahasa Yunani yaitu ethikos, ethos yang berarti adat, kebiasaan atau praktik. Kalau kita membatasi pada asalusul istilah tersebut, maka etika berarti ilmu tentang apa yang biasa dilakukan atau tentang adat kebiasaan (Zaprulkhan, 2013:168).

Sedangkan dalam kamus besar Bahasa indonesia, etika didefinisikan sebagai ilmu tentang apa yang baik dan apa yang buruk, dan tentang hak dan kewajiban moral. Disitu, etika dijelaskan dengan membedakan tiga arti: (1) Ilmu tentang apa yang baik dan apa yang buruk dan tentang hak dan kewajiban moral (akhlak); (2) Kumpulan asas atau nilai yang berkenaan dengan akhlak; dan (3) Nilai mengenai benar dan salah yang dianut suatu golongan atau masyarakat.

Dari segi etimologi (ilmu asal-usul kata), etika berasal dari bahasa Yunani, ethos yang berarti watak kesusilaan atau adat. Dalam Kamus Umum Bahasa
Indonesia, etika diartikan ilmu pengetahuan tentang asas-asas akhlak (moral). Dari pengertian kebahasaan ini terlihat bahwa etika berhubungan dengan upaya menentukan tingkah laku manusia.

Adapun arti etika dari segi istilah telah dikemukakan para ahli dengan ungkapan yang berbeda-beda sesuai dengan sudut pandangnya. Ahmad Yamin misalnya mengartikan etika adalah ilmu yang menjelaskan arti baik dan buruk, menerangkan apa yang seharusnya dilakukan oleh manusia didalam perbuatan mereka dan menunjukkan jalan untuk melakukan apa yang seharusnya diperbuat.

Menurut Ki Hajar Dewantara etika adalah ilmu yang mempelajari soal kebaikkan (dan keburukkan) didalam hidup manusia semuanya, teristimewah yang mengenai gerak gerik pikiran dan rasa yang dapat merupakakan pertimbangan dan perasaan sampai mengenai tujuan yang dapat merupakakan perbuatan (Nata, 1996:8788).

Dari beberapa definisi etika tersebut di atas dapat segera diketahui bahwa etika berhubungan dengan empat hal sebagai berikut. Pertama dilihat dari segi objek pembahasaanya, etika berupaya membahas perbuatan yang dilakukan oleh manusia. Kedua dilihat dari sumbernya, etika bersumber pada akal pikiran atau filsafat. Ketiga, dilihat dari segi fungsinya, etika berfungsi sebagai penilai, penentu dan penetap terhadap suatu perbuatan yang dilakukan oleh manusia, yaitu apakah perbuatan tersebut akan dinilai baik, buruk, mulia, terhormat, hina dan sebagainya. Keempat dilihat dari segi sifatnya, etika bersifat relatif yakni dapat berubahubah sesuai dengan tuntutan zaman.

\section{Moral}

Moral berasal dari kata latin mores yang artinya tata cara dalam kehidupan, 
adat istiadat, atau kebiasaan. Moral pada dasarnya merupakan rangakaian nilai tentang berbagai macam perilaku yang harus di patuhi (Mohammad Ali dan Mohammad Asrori, 2012:151).

Istilah moral berasal dari kata latin "mos" (moris), yang berarti adat istiadat, kebiasaan, peraturan/nilai-nilai atau tatacara kehidupan. Sedangkan moralitas merupakan kemauan untuk menerima dan melakukan peraturan, nilai-nilai atau prinsip-prinsip moral. Nilai-nilai moral itu, seperti (a) seruan untuk berbuat baik kepada orang lain, memelihara ketertiban dan keamanan, memelihara kebersihan dan memelihara hak orang lain, dan (b) larangan mencuri, berzina, membunuh, meminum-minuman keras dan berjudi. Seseorang dikatakan bermoral, apabila tingkah laku orang tersebut sesuai dengan nilai-nilai moral yang dijunjung tinggi oleh kelompok sosialnya (Syamsu Yusuf LN, 2011:132).

\section{Akhlak}

Kata "akhlak" (akhlaq) berasal dari bahasa Arab, merupakan bentuk jamak dari "khuluq" yang menurut bahasa berarti bdi pekerti, perangai, tingkah laku, atau tabiat. Kata tersebut mengandung segi persesuaian dengan kata "khalq" yang berarti kejadian. Ibnu 'Athir menjelaskan bahwa khuluq itu adalah gambaran batin manusia yang sebenarnya (yaitu jiwa dan sifat-sifat batiniah), sedang khalq merupakan gambaran bentuk jasmaninya (raut muka, warna kulit, tinggi rendah badan, dan lain sebagainya). Kata khuluq sebagai bentuk tunggal dari akhlak, tercantum dalam Al-Qur'an surah AlQalam (68):4:

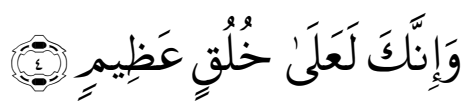

Artinya: "Sesungguhnya engkau (Muhammad) berada di atas budi pekerti yang agung"

Secara terminologis, terdapat beberapa definisi akhlak yang dikemukkan oleh para ahli. Ahmad Amin mendefinisikan akhlak sebagai "kehandak yang dibiasakan". Imam AlGhazali menyebutkan bahwa akhlak adalah "sifat yang tertanam dalam jiwa yang menimbulkan perbuatanperbuatan dengan mudah tanpa memerlukan pemikiran dan pertimbangan". Sedangkan Abdullah Darraz mengemukakan bahwa akhlak adalah "suatu kekuatan dalam kehendak yang mantap yang membawa kecenderungan kepada pemilihan pada pihak yang benar (akhlak yang baik) atau pihak yang jahat (akhlak yang buruk)" (Didiek Ahmad Supadie dan Sarjuni, 2012:216-217).

Akhlak adalah watak dan karakter yang melekat pada diri seseorang, dan karenanya sifatnya spontan. Namun demikian, akhlak juga bia ditanamkan, dilatih, dan dibiasakan melalui pendidikan. Itulah sebabnya, disetiap lembaga pendidikan (sekolah, madrasah, dan pesantren) terdapat materi pendidikan akhlak. Akhlak juga disebut moral, yakni norma-norma yang mengatur perilaku manusia berdasarkan sember-sumber tertentu (Ismatu Ropi,dkk, 2012:96).

Dari ketiga istilah pengertian (etika, moral, dan akhlak), maka jelaslah bahwa antara ketiganya mempunyai kesamaan yaitu menentukan nilai baik dan buruk sikap serta perbuatan manusia. Bagi akhlak standarnya adalah Al-Qur'an dan Sunnah, sedangkan bagi etika standarnya adalah pertimbangan akal pikiran, dan bagi moral standarnya adat kebiasaan umum yang berlaku. Salah satu unsur dasaar akhlak pendidikan yang penting adalah bahwa peserta didik sebagai individu yang 
merupakan inti dalam pembangunan masyarakat.

\section{Pergaulan dan Macam-macam Pergaulan Definisi Pergaulan}

Pengertian pergaulan secara etimologi kata bergaul indentik dengan kata "gaul" mengulas tentang kata gaul pada peradaban kejayaan romawi ada suku yang bernama suku gaul yang pada waktu itu bangsa gaul menjadi budak kaum romawi, konon katanya mereka diberi nama bangsa gaul dikarenakan mereka memiliki sifat dan karakteristik yang berbeda dengan bangsa atau suku lainnya. Sedangkan pengertian pergaulan secra terminologi yaitu menjunjung tinggi kebersamaan, persekawanan, dan persaudaraan yang dimana mereka lebih cenderung memiliki sifat afatisme dan hedonisme yang artinya mereka akan melakukan apapun untuk mencapai tujuannya.

Pergaulan adalah kontak langsung antara individu dengan individu lain, atau antara pendidik dengan anak didik. Pergaulan jugam memungkinkan menimbulkan pengertian yang mendalam antara tugas pendidik, yang wajib mendidik dan tugas anak didik yang wajib belajar. Saling mengetahui karena pergaulan tersebut dapat memudahkan usaha bimbingan dan pertolongan agar dilaksanakan dengan sebaik-baiknya (Abdullah Idi dan Safarina, 2011:83).

\section{Macam-macam Pergaulan}

\section{Pergaulan dalam Keluarga}

Orang tua mempunyai peranan pertama dan utama bagi anak-anaknya selama anak belum dewasa dan mampu terdiri sendiri. Untuk membawa anak kepada kedewasaan, orang tua harus memberi teladan yang baik karena anak suka mengimitasi kepada orang yang lebih tua atau orang tuanya. Dengan teladan yang baik, anak tidak merasa di paksa.

Secara tidak langsung setiap anak berguru kepada saudara-saudaranya sehingga anak menjadi tahu bahwa dia merasa wajib memberi sebagaimana dia merasa perlu pemberian, baik materi maupun nonmateri. Antaranak dalam keluarga belajar tukar-menukar pengalaman sehingga semakin banyaklah hal-hal yang diketahui tentang baik dan buruk, hak dan kewajiban, tentang saling menyayangi, dan sebagainya dengan adanya hubungan satu sama lain.

\section{Pergaulan dalam Sekolah}

Sebagai lembaga pendidikan formal, sekolah terdiri dari pendidik dan anak didik. Antara mereka sudah barang tentu terjadi adanya saling hubungan, baik antara guru dengan murid-muridnya maupun antara murid dengan murid.

Guru-guru sebagai pendidik, dengan wibawanya dalam pergaulan membawa murid sebagai anak didik ke arah kedewasaan. Memanfaatkan pergaulan sehari-hari dalam pendidikan merupakan cara yang paling baik dan efektif dalam pembentukan pribadi dan dengan cara ini pula maka hilanglah jurang pemisah antara guru dan anak didik.

\section{Pergaulan dalam Masyarakat}

Dalam konteks pendidikan, lingkungan masyarakat merupakan lembaga pendidikan selain keluarga dan sekolah yang akan membentuk kebiasaan, pengetahuan, minat dan sikap, kesusilaan, kemasyarakatan, dan keagamaan anak. Dimasyarakatlah anak melakukan pergaulan yang berlangsung secara informal baik dari para tokoh masyarakat, pejabat atau penguasa, para pemimpin agama, dan sebagainya. 
Dengan demikian, dalam pergaulan sehari-hari antara seseorang dengan tokoh agama dan tokoh masyarakat mengandung gejala-gejala pendidikan karena para tokoh tersebut dalam pergaulannya mengarah kepada pengaruh yang positif, menuju kepada tujuan yang mencakup nilai luhur.

Pergaulan sehari-hari antara anak dengan anak lainnya dalam masyarakat juga ada yang setaraf dan ada lebih dewasa di bidang tertentu. Teguran anak yang lebih dewasa, terhadap anak yang nakal, yang jorok, yang melakukan perbuatan-perbuatan berbahaya, dan sebagainya. (Hasbullah:2009:115-117)

\section{Jenis-jenis Etika Bergaul Islami}

Jenis-jenis bergaul islami telah diatur sebagai berikut:

\section{Pergaulan muda-mudi}

Pertama, menjaga pandangan terhadap lawan jenis yang bukan muhrimnya. Pria dan wanita harus dapat menjaga dan mengendalikan pandangan matanya dan memelihara nafsu seksualnya, sebagaimana di perintahkan oleh Allah dalam firmanNya dalam surat An-Nur ayat : 30 :

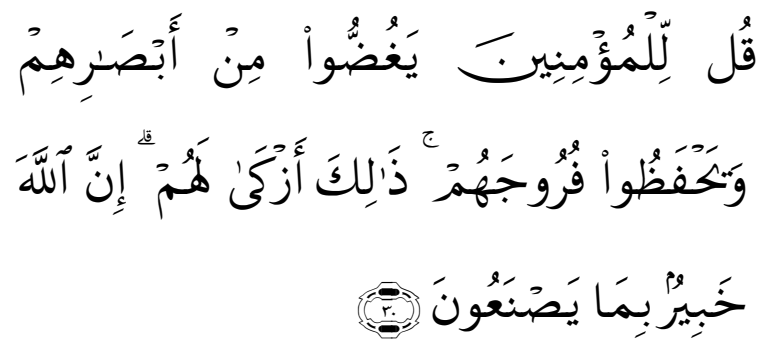

Artinya: "Katakanlah kepada laki-laki yang beriman, hendaklah mereka memelihara pandangan mata mereka dan memelihara kemaluannya; cara yang demikian itu lebih suci bagi mereka. Sesungguhnya Allah Maha Mengetahui segala perbuatanmu. (QS. An-Nur 24:30).
Ayat tersebut memerintahkan kepada kaum pria untuk memandang lawan jenisnya (kaum wanita), dengan pandangan secara wajar, tidak boleh memandang dengan penuh nafsu birahi.

Perintah menundukkan pandangan dan larangan memandang lain jenis itu ditujukan pula kepada kaum wanita sebagaimana dapat dibaca dalam ayat : 31 surat An-Nur. Allah berirman yang artinya:

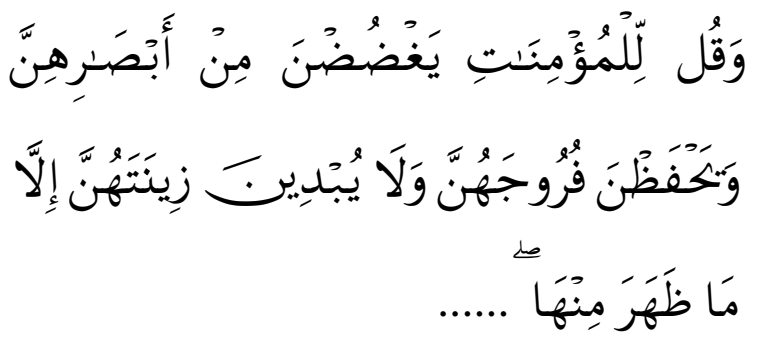

Artinya: "Dan katakanlah kepada wanita yang beriman; hendaklah mereka menahan pandangannya dan memelihara kemaluannya. (QS. An-Nur 24:31).

Kedua, pengaturan shaf laki-laki dan perempuan dalam shalat berjam'ah, adalah termasuk usaha pencegahan dari kemungkinan akibat jelek bagi kedua belah pihak dan rusaknya sholat itu sendiri. Seandainya kaum wanita diperbolehkan campur dengan laki-laki atau jika diperkenankan wanita itu menempati shaf dimuka laki-laki, maka jelas kontakan nafsu birahi dalam sholat itu sulit dielakan. Akibatnya sholat menjadi rusak dan tidak akan mendatangkan ketenangan dan kebahagiaan, tetapi hanya menjadikan hati resah dan gelisah.

Ketiga, larangan berduaan sepasang muda-mudi tanpa disertai mahramnya. Larangan tersebut berdasarkan Hadits berikut ini :

Artinya: "Rasulullah saw. Bersabda : Jangan sekali-kali bersepisepian seorang pria dan wanita kecuali wanita itu bersama mahramnya. (HR. Muttafaq

Jurnal Al-hikmah Vol. 13, No. 2, oktober 2016 ISSN 1412-5382 
'alaih/riwayat Al-Bukhari dan Muslim).

Hadits tersebut sebagai landasan untuk menetapkan etika pergaulan antara pria dan wanita yang halal nikah. Larangan dalam hadits tersebut mempunyai tujuan yang sama dengan perintah memelihara pandangan mata dan lainnya, yaitu demi keselamatan muda-mudi itu sendiri.

Kalau saling pandang memandang dengan nafsu syahwat dilarang, maka berduaan lebih dilarang lagi, karena jelas besar kemungkinan terjadinya pelanggaran seksual. Untuk menjaga menjaga akibat buruk semacam itu Agama menetapkan norma, supaya phak wanita itu harus disertai mahramnya. Paling tidak mereka harus disertai orang lain agar tidak terjerumus dalam noda dan dosa yang lebih besar dari itu. (Abubakar Muhammad, 1994:129-131)

Keempat, mengucapkan dan menjawab salam. Islam mengajarkan kepada sesama muslim untuk saling bertukar salam apabila bertemu atau bertamu, supaya rasa kasih sayang sesama dapat selalu terpupuk dengan baik. Rasulullah saw bersabda:

Artinya : "Kamu tidaklah akan masuk syurga sebelum beiman, dan tidak akan beriman sebelum berkasih sayang. Maukah kamu aku tunjukkan suatu amalan yang akan dapat memupuk rasa kasih sayang sesamamu ? Yaitu senantiasalah mengucapkan salam sesamamu." (HR. Muslim). (Yunahar Ilyas, 2002:210)

Salam yang diucapkan minimal adalah "Assalamu'alaikum". Tetapi akan lebih baik dan lebih besar pahalanya apabila di ucapkan secara lengkap. Mengucapkan salam hukumnya sunnah, tetapi menjawabnya wajib minimal dengan salam yang seimbang. Allah SWT berfirman:

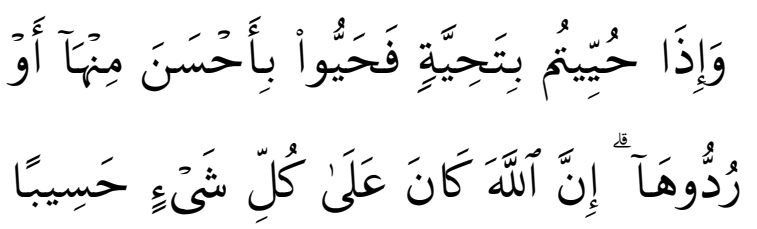

Artinya: "Apabila kamu dihormati dengan suatu penghormatan, maka balaslah penghormatan itu dengan yang lebih baik, atau balaslah (dengan serupa). Sesungguhnya Allah memeperhitungkan segala sesuatu." (QS. An-Nisa' 4:86).

Bila bertamu yang mengucapkan salam lebih dahulu adalah yang bertamu, tetapi untuk bertemu yang terlebih dahulu mengucapkan salam adalah yabg berada di atas kendaraan kepada yang berjalan kaki, yang berjalan kaki kepada yang duduk, yang sedikit kepada yang banyak, dan yang lebih muda kepada yang lebih tua.

Salam tidak hanya diucapkan waktu saling bertemu, tapi juga tatkala mau berpisah. Jika dalam rombongan, baik yang mengucapkan maupun yang menjawab salam boleh hanya salah seorang dari anggota rombongan tersebut. Rasulullah saw melarang orang islam mengucapkan dan menjawab salam ahlul kitab (Yahudi dan Nasrani). Pria boleh mengucapkan salam kepada wanita dan begitu pula sebaliknya.

\section{Etika Pergaulan Remaja Dalam Islam}

Etika mesti merupakan sesuatu yang mutlak supaya tidak membingungkan, karena etika Islam bukan sekedar teori tetapi juga pernah diperaktekkan oleh sejumlah manusia dalam suatu zaman, sehingga mereka muncul sebagai penyelamat dunia dan pelopor peradaban. Etika Islam berbeda dengan etika yang lain, mempunyai sosok dalam diri Muhammad saw. Telah menjadi 
contoh indah dari etika Islam. Etika Islam juga bersumber dalam QS.AlBaqarah (2):2 sebagai berikut:

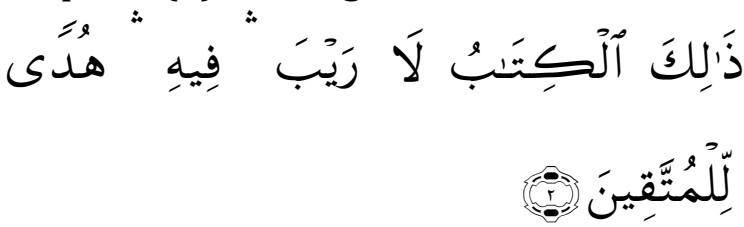

Artinya: “Kitab (al-Qur'an) ini tidak ada keraguan padanya; petunjuk bagi mereka yang bertaqwa".

Oleh karena itu kedudukan akhlak dalam kehidupan manusia menempati tempat yang penting sekali, baik sebagai individu maupun sebagai anggota masyarakat dan bangsa. Sebab jatuh bangunnya, jaya hancurnya, sejahtera rusaknya suatu bangsa dan masyarakat, tergantung kepada bagaimana akhlaknya. Apabila akhlaknya buruk (tidak berakhlak) maka rusaklah lahir dan batinnya.

Al-Qur'an berkali-kali menyatakan bahwa imbalan (hukuman) terhadap keburukan adalah keburukan serupa, yang dimaksudkan sebagai penolakan (negasi) terhadap yang buruk, tetapi imbalan (pahala) terhadap kebaikan justru dilipat gandakan berkali-kali, sebagaimana QS.Al-An'am (6):160 yang artinya :

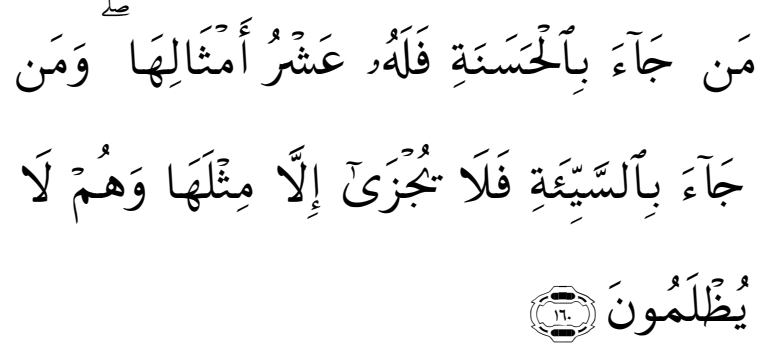

Artinya: "Barang siapa membawa amal yang baik maka baginya (pahala) sepuluh kali lipat amalnya; dan barang siapa membawa perbuatan yang jahat maka dia tidak diberi pembalasan melainkan seimbang dengan kejahatannya sedang mereka sedikitpun tidak dianiaya (dirugikan)"
Remaja berasal dari kata lain adolensence yang berarti tumbuh atau tumbuh menjadi dewasa. Istilah adolensence mempunyai arti yang lebih luas lagi yang mencakup kematangan mental, emosional sosial dan fisik. Hal senada di ungkapkan Santrock bahwa remaja (adolensence) diartikan sebagai masa perkembangan transisi antara anak dan masa dewasa yang mencakup perubahan biologis, kognitif, dan sosialemosional.

Para ahli umumnya sepakat bahwa rentangan masa remaja berlangsung dari usia 11-13 tahun sampai dengan 18-20 tahun. Pada rentangan periode ini terdapat beberapa indikator perbedaan yang signifikan, baik secara kuantitatif maupun kualitatif. Oleh karena itu, para ahli mengklasifikasikan masa remaja ini ke dalam dua bagian yaitu : (1) remaja awal (11-13 tahun s/d 14-15 tahun); dan (2) remaja akhir (14-16 tahun s/d 18-20 tahun).

Masa remaja ditandai dengan adanya berbagai perubahan, baik secara fisik maupun psikis, yang mungkin saja dapat menimbulkan problema tertentu bagi si remaja. Apabila tidak disertai dengan upaya pemahaman diri dan pengarahan diri secara tepat, bahkan dapat menjurus pada berbagai tindakan kenakalan remaja dan kriminal. Problema yang mungkin timbul pada masa remaja diantaranya: (1) problema berkaitan dengan perkembangan fisik dan motorik, berkaitan dengan perkembangan kognitif dan bahasa, (2) problema berkaitan dengan perkembangan prilaku sosial, moralitas dan keagamaan, problema berkaitan dengan perkembangan kepribadian dan emosional. Masa remaja disebut juga masa untuk menemukan identitas diri (self identity).

Islam telah mengatur etika pergaulan remaja prilaku tersebut merupakan batasan-batasan yang dilandasi nilai-nilai agama. Oleh karena 
itu prilaku tersebut harus diperhatikan, dipelihara dan dilaksanakan oleh para remaja. Perilaku yang menjadi batasan dalam pergaulan adalah : (1) menutup aurat, Islam telah mewajibkan perempuan untuk menutup aurat demi menjaga kehormatan diri dan kebersihan hati. (2) menjauhi perbuatan zina, Islam adalah agama yang menjaga kesucian. Dalam Al-Qur'an Allah berfirman dalam surat Al-Isra' ayat 32 yang artinya. "dan janganlah kamu mendekati zina itu adalah suatu perbuatan yang keji dan suatu jalan buruk".

Dalam tata cara pergaulan remaja semua agama dan tradisi mengatur tata cara pergaulan tersebut. Agama Islam sebagai pedoman hidup ummatnya juga telah mengatur tata cara pergaulan remaja yang dilandasi nilai-nilai agama. Tata cara itu meliputi ; 1) Mengucapkan salam, 2) Meminta izin, 3) Menghormati yang lebih tua dan menyayangi yang lebih muda, 4) Bersikap santun dan tidak sombong, 5) Berbicara dengan perkataan yang sopan, 6) Tidak boleh saling menghina, 7) Tidak boleh saling benci dan iri hati, 8) Mengisi waktu luang dengan kegiatan yang bermanfaat, 9) Mengajak untuk berbuat kebajikan. (Andi Anirah dan Sitti Hasnah, 2013:291 Jurnal Istiqra').

\section{Konsep Operasional}

Sesuai dengan judul dan tujuan penelitian ini agar lebih terarah maka disusunlah konsep operasional penerapan etika pergaulan Islami, peneliti mengambil teori yang di kemukakan oleh Abubakar Muhammad dalam buku pembinaan manusia dalam Islam dan menurut Anirah dan Hasnah (2013:291) dengan indikator sebagai berikut: (1) Santri harus menjaga pandangannya terhadap lawan jenis yang bukan muhrimnya; (2) Santri lakilaki dan perempuan harus mengetahui dan memahami etika pengaturan shaf dalam shalat; (3) Santri laki-laki dan perempuan dilarang berduaan tanpa di sertai mahramnya (Abubakar Muhammad, 1994:128); (4) Santri apabila bertemu atau memulai aktivitas memberi salam dan menjawab salam; (5) Santri ketika berpergian atau keluar dari ruang belajar meminta izin dengan orang tua dan guru ketika disekolah; (6) Santri harus menghormati yang lebih tua dan menyayangi yang lebih muda; (7) Santri harus bersikap santun dan tidak sombong kepada orang-orang ketika sedang melakukan aktivitas; (8) Santri sebaiknya berbicara dengan sopan; (9) Santri tidak boleh saling menghina ketika ada teman nya yang sedang kesusahan; (10) Santri tidak boleh saling benci dan iri terhadap orang lain apabila orang tersebut memiliki kelebihan dari pada kita; (11) Santri mengisi waktu luang dengan kegiatan yang bermanfaat; dan (12) Santri suka mengajak teman berbuat kebajikan .

\section{METODE PENELITIAN}

Jenis penelitian ini adalah deskriptif, yaitu penelitian yang dilakukan untuk mengetahui nilai variabel mandiri, baik satu variabel atau lebih (indepeden) tanpa membuat perbandingan, atau menghubungkan dengan variabel yang lain. (Sugiyono, 1999:11)

Penelitian dilakukan di Pesantren Jabal Nur Kecamatan Kandis Kabupaten Siak. Penelitian ini memakan waktu 4 bulan mulai dari Desember 2015-Maret 2016.

Dalam penelitian ini yang menjadi subjeknya ialah santri/santriwati di pesantren Jabal Nur Kecamatan Kandis Kabupaten Siak sedangkan objeknya ialah etika pergaulan islami santri Madrasah Aliyah (MA) di pesantren Jabal Nur Kecamatan Kandis Kabupaten Siak.

AriKunto, (2013: 117) menyatakan bahwa populasi adalah keseluruhan 
subjek penelitian. Dalam penelitian ini populasi adalah seluruh santri/santriwati yang ada di Pesantren
Jabal Nur Kandis Siak dengan jumlah santri 350.

Tabel 1: Populasi Penelitian

\begin{tabular}{ccc}
\hline No & Kelas & Populasi \\
\hline 1 & Kelas X & 175 santri/santriwati \\
\hline 2 & Kelas XI & 105 santri/santriwati \\
\hline 3 & Kelas XII & 70 santri/santriwati \\
\hline & Jumlah & 350 santri/santriwati
\end{tabular}

Sumber data : TU Pesantren Jabbal Nur Kandis Siak

Dan yang menjadi sampel dalam penelitian ini adalah santri/santriwati pesantren Jabal Nur Kandis. Pengambilan sampel ini berdasarkan pendapat Suharsimi Ari Kunto apabila subjek kurang dari seratus (100) lebih baik diambil semua sehingga penelitian ini merupakan penelitian populasi. Salanjutnya jika jumlah subjeknya lebih besar, dapat diambil antara $10-15 \%$ atau $20-25 \%$. Sehingga dalam penelitian ini penulis mengambil sampel sebesar $25 \%$ dari populasi yang ada, karena penulis melihat tinggkat homogenitas populasi yang ada cukup tinggi sehingga dengan pengambilan sampel sebanyak $25 \%$ persen sudah mampu mewakili populasi yang ada.

Teknik pengambilan sampel yang digunakan oleh penulis dalam penelitian ini adalah teknik Randon Sampling ini peneliti memberikan kesempatan yang sama kepada setiap subjek untuk diambil sebagai anggota sampel. Dan semua subjek mempunyai peluang yang sama untuk diteliti.

\section{Teknik Pengumpulan Data}

Untuk mengumpulkan data-data yang diperlukan dalam penelitian ini, maka penulis menggunakan Angket. Angket adalah kumpulan pertanyaan yang diajukan secara tertulis kepada seseorang ( responden), dan cara menjawabnya juga dilakukan dengan terrtulis (Rizal Dairi, 2013:66).
Menurut Bungin (2008:121) teknik dokumentasi adalah salah satu metode pengumpulan data yang digunakan dalam penelitian sosial untuk menelusuri data historis. Teknik dokumen meski pada mulanya jarang diperhatikan dalam penelitian kualitatif, pada masa kini menjadi salah satu bagian yang penting dan tak terpisahkan dalam penelitian kualitatif. Hal ini disebabkan oleh adanya kesadaran dan pemahaman baru yang berkembang di para peneliti bahwa banyak sekali data yang tersimpan dalam bentuk dokumen dan artefak. Penggalian sumber data lewat studi dokumen menjadi pelengkap bagi proses penelitian kualitatif (Imam Gunawan, 2014:177).

\section{Teknik Pengolahan Data}

Teknik pengolahan data yang diperlukan dalam penelitian ini adalah: (a) Penyuntingan (Editing). Data-data yang sudah di peroleh akan diperiksa apakah ada kesalahan atau ketidaklengkapan dalam pengisian; (b) Pengkodean (Coding). Dalam pengkodean ini tiap data itu diberikan symbol atau tanda baik dalam angka maupun huruf; (c) Pentabulasian (Tabulating). Dalam pentabulasian, nilai data yang serupa di kelompok dalam tabel secara teliti kemudian di hitung dan di jumlahkan beberapa item-item yang termasuk kedalam satu kategori; dan (d) Skor (Skoring). Skoring adalah

Jurnal Al-hikmah Vol. 13, No. 2, Oktober 2016 ISSN 1412-5382 
penentuan jumlah skor (Rizal Dairi, 2013:78-80).

Dalam penelitian ini ditetapkan pengukuran data dengan penilaian dalam kategori yaitu : baik, cukup baik, kurang baik, tidak baik, sangat tidak baik dengan memakai persentase hasil ukuran sebagai berikut ini : (a) Etika Pergaulan Islami Santri Madrasah Aliyah (MA) Di Pesantren Jabal Nur Kecamatan Kandis Kabupaten Siak dapat dikatakan "Baik" apabila hasil pengukuran mencapai 81\% - 100\%; (b) Etika Pergaulan Islami Santri Madrasah Aliyah (MA) Di Pesantren Jabal Nur Kecamatan Kandis Kabupaten Siak dapat dikatakan "Cukup Baik" apabila hasil pengukuran mencapai 61\% - 80\%; (c) Etika Pergaulan Islami Santri Madrasah Aliyah (MA) Di Pesantren Jabal Nur Kecamatan Kandis Kabupaten Siak dapat dikatakan "Kurang Baik" apabila hasil pengukuran mencapai 41\% - 60\%: (d) Etika Pergaulan Islami Santri Madrasah Aliyah (MA) Di Pesantren Jabal Nur Kecamatan Kandis Kabupaten Siak dapat dikatakan "Tidak Baik" apabila hasil pengukuran mencapai 21\% - 40\%; dan (d) Etika Pergaulan Islami Santri Madrasah Aliyah (MA) Di Pesantren Jabal Nur Kecamatan Kandis Kabupaten Siak dapat dikatakan "Sangat Tidak Baik" apabila hasil pengukuran mencapai $0 \% \quad-\quad 20 \%$ (Suharsimi Arikunto, 1997:246).

\section{Teknik Analisis Data}

Data yang terkumpul dipisahkan menurut kelompok, kemudian dianalisis dengan teknik deskriptif. Dalam mengukur standar presentasenya ini, penulis mengambil dari buku Suharsimi Arikunto, yaitu sebagai berikut:

76\%-100\% dikatakan baik, 60-75\% cukup dan kurang dari $60 \%$ dikatakan kurang baik. (Suharsimi Arikunto, 2002: 30)

Teknik analisis data yang di pergunakan dalam penelitian ini adalah menghitung presentase dengan menggunakan rumus sebagai berikut:

$$
P=\frac{F}{N} \times 100 \%
$$

$$
\begin{aligned}
& \text { Keterangan }: \mathrm{P}=\text { Presentase } \\
& \qquad \mathrm{F}=\text { Frekuensi } \\
& \mathrm{N}=\text { Jumlah Responden. }
\end{aligned}
$$

\section{HASIL DAN PEMBAHASAN \\ Gambaran Umum Lokasi Penelitian Sejarah Berdirinya Pesantren Jabal Nur}

Madrasah Aliyah Jabal Nur didirikan pada tahun 2007 oleh Bapak K.H. Muhammad Ali Muchsin, B.A. Pada saat itu tempatnya disebuah desa yang latar belakang pendidikannya masih terbelakang, jauh dari tuntunan agama Islam, yang sekarang bernama Kandis. Seiringnya waktu berjalan dan keinginan yang begitu besar untuk membangun tempat pendidikan Agama akhirnya tercapai juga.

Namun untuk mewujudkan keinginan tersebut beliau harus menghadapi berbagai macam rintangan, terutama masalah dana dan bangunan. Dengan segenap usaha dan upaya niatan tersebut baru dapat terlaksanan tahun 2004 yakni dengan berdirinya Madrasah Tsanawiyah Jabal Nur yang bernaung didalam yayasan Jabal Nur Takwallah (Pondok pesantren Jabal Nur). Setelah sekian lama berjalan akhirnya pada tahun 2007 MTs tersebut berhasil menamatkan santrinya.

\section{Visi Madrasah Aliyah(MA) Pesantren Jabal Nur Kandis}

Adapun visi Madrasah Aliyah (MA) Pesantren Jabal Nur Kandis adalah sebagai berikut : (1) Menjadi madrasah yang dinamis, inovatif dan reformatif dalam bingkai jiwa taqwallah; (2) Menjadi pusat pemantapan akidah dan pembekalan dasar syariat islam sebagai 
landasan normatif hidup dan kehidupan; dan (3) Menjadi salah satu penggerak dan pembentukan masyarakat madani dalam konteks keindonesiaan dalam bingkai akhlakul karimah sebagai landasan moral untuk etos perjuangan hidup dan kehidupan.

\section{Misi Madrasah Aliyah(MA) Pesantren Jabal Nur Kandis}

Sedangkan misi Madrasah Aliyah (MA) Pesantren Jabal Nur Kandis adalah sebagai berikut : "MENGANTARKAN SELURUH KOMPONEN PONDOK PESANTREN JABAL NUR DAN MASYARAKAT DALAM PEMBENTUKAN JIWA TAQWALLAH DAN APLIKASINYA MELALUI: (1) Pembekalan dan pemantapan dasar Iman (Akidah Tauhid ), Syariat Islam ( Fiqih ) dan Akhlakul Karimah; (2) Mengobarkan dan menggerakkan semangat Amar Makruf Nahi Munkar dan keteladanan; (3) Membentuk civitas madrasah berwawasan global yang Dinamis, Inovatif, Idealis, Reformatif dan dedikasi dengan loyalitas yang tinggi sebagai Jiwa Ahlulsunnah wal Jamaah; dan (4) Membentuk santri yang berkualitas dan mandiri dalam bingkai Jiwa Takwallah sebagai Dinamisator, Motivator, Katalisator pembangunan masyarakat madani."

\section{Penyajian Hasil Penelitian}

Data hasil penelitian diperoleh melalui proses penelitian yang telah dilakukan oleh peneliti. Dengan subjek penelitian santri Madrasah Aliyah (MA) Pesantren Jabal Nur Kecamatan Kandis Kabupaten Siak yang berjumlah 86 santri. Pengumpulan data pada penelitian ini pelaksanaannya dilakukan oleh peneliti sendiri dengan dua cara yaitu metode angket atau kuisioner dan dokumentasi. Kemudian hasil disajikan dalam bentuk tabel.

Tabel 2: Tanggapan Responden Tentang Menjaga Pandangan Terhadap Lawan Jenis

\begin{tabular}{clcc}
\hline No & Klasifikasi Jawaban & Jumlah Responden & Persentasi (\%) \\
\hline 1 & Sangat setuju & 40 & $46,51 \%$ \\
\hline 2 & Setuju & 38 & $44,19 \%$ \\
\hline 3 & Kurang setuju & 4 & $4,65 \%$ \\
\hline 4 & Tidak setuju & 3 & $3,49 \%$ \\
\hline 5 & Sangat tidak setuju & 1 & $1,16 \%$ \\
\hline & Jumlah & 86 & $100 \%$ \\
\hline
\end{tabular}

Berdasarkan tabel di atas, tergambar bahwa 40 santri Madrasah Aliyah di Pesantren Jabal Nur dari 86 responden yang diteliti atau 46,51\% santri "Sangat setuju" menjaga pandangan terhadap lawan jenis. Di samping itu ditemukan juga data dimana 38 orang santri Madrasah yang mengisi angket jika di persentasekan sama dengan $(44,19 \%)$ atau "Setuju". Selain itu ditemukan juga data dimana 4 orang santri Madrasah Aliyah di Pesantren Jabal Nur dari 86 respoden atau (4,65\%). Menjawab "Kurang Setuju" terindikasi menjaga pandangan terhadap lawan jenis.

Di lain sisi terdapat pula data di mana ada 3 orang santri Madrasah Aliyah di Pesantren Jabal Nur atau jika dipersentasekan sama dengan $(3,49 \%)$ "Tidak Setuju", terindikasi dalam menjaga pandangan terhadap lawan jenisnya. Data selanjutnya ditemukan dimana 1 orang santri Madrasah Aliyah di Pesantren Jabal Nur dari 86 responden atau $(1,16 \%)$. Menjawab "Sangat Tidak Setuju" terindikasi dalam 
menjaga pandangan terhadap lawan jenis.

Tabel 3: Mengetahui Dan Memahami Etika Pengaturan

Shaf Dalam Shalat Dengan Benar.

\begin{tabular}{clcc}
\hline No & Klasifikasi Jawaban & Jumlah Responden & Persentasi (\%) \\
\hline 1 & Sangat setuju & 50 & $58,14 \%$ \\
\hline 2 & Setuju & 22 & $25,581 \%$ \\
\hline 3 & Kurang setuju & 12 & $13,953 \%$ \\
\hline 4 & Tidak setuju & 1 & $1,163 \%$ \\
\hline 5 & Sangat tidak setuju & 1 & $1,163 \%$ \\
\hline & Jumlah & 86 & $100 \%$ \\
\hline
\end{tabular}

Berdasarkan tabel di atas, tergambar bahwa 50 santri Madrasah Aliyah di Pesantren Jabal Nur dari 86 responden yang diteliti atau 58,14\% santri "Sangat setuju" mengetahui dan memahami etika pengaturan shaf dalam shalat dengan benar. Di samping itu ditemukan juga data dimana 22 orang santri yang mengisi angket jika di persentasekan sama dengan $(25,581 \%)$ atau "Setuju". Selain itu ditemukan juga data dimana 12 orang santri Madrasah Aliyah di Pesantren Jabal Nur dari 86 respoden atau $(13,953 \%)$.
Di lain sisi terdapat pula data di mana ada 1 orang santri Madrasah Aliyah di Pesantren Jabal Nur atau jika dipersentasekan sama dengan $(1,163 \%)$ "Tidak Setuju". Data selanjutnya ditemukan dimana 1 orang santri Madrasah Aliyah di Pesantren Jabal Nur dari 86 responden atau (1,16\%). Menjawab "Sangat Tidak Setuju" terindikasi dalam mengetahui dan memahami etika pengaturan shaf dalam shalat dengan benar.

Tabel 4: Larangan Berduaan Sepasang Muda-Mudi Tanpa Disertai Mahramnya

\begin{tabular}{clcc}
\hline No & Klasifikasi Jawaban & Jumlah Responden & Persentasi (\%) \\
\hline 1 & Sangat setuju & 35 & $40,698 \%$ \\
\hline 2 & Setuju & 30 & $34,884 \%$ \\
\hline 3 & Kurang setuju & 4 & $4,651 \%$ \\
\hline 4 & Tidak setuju & 14 & $16,279 \%$ \\
\hline 5 & Sangat tidak setuju & 3 & $3,488 \%$ \\
\hline & Jumlah & 86 & $100 \%$ \\
\hline
\end{tabular}

Berdasarkan tabel di atas, tergambar bahwa 35 santri Madrasah Aliyah di Pesantren Jabal Nur dari 86 responden yang diteliti atau 40,698\% santri "Sangat setuju" larangan berdua sepasang muda-mudi tanpa disertai mahramnya. Di samping itu ditemukan juga data dimana 30 orang yang mengisi angket jika di persentasekan sama dengan $(34,884 \%)$ atau "Setuju" dalam larangan berdua sepasang muda-mudi tanpa disertai mahramnya. Selain itu ditemukan juga data dimana 4 orang santri (4,651\%). Menjawab "Kurang
Setuju". Di lain sisi terdapat pula data di mana ada 14 orang santri atau jika dipersentasekan sama dengan $(16,279 \%)$ menjawab "Tidak Setuju".

Data selanjutnya ditemukan dimana 3 orang santri Madrasah Aliyah di Pesantren Jabal Nur dari 86 responden atau $(3,488 \%)$. Menjawab "Sangat Tidak Setuju" terindikasi terhadap larangan berdua sepasang muda-mudi tanpa disertai mahramnya. Bila dilihat jawaban ini 3 orang responden dari 86 responden, sangat terlalu memprihatinkan sebab data ini 2, oktober 2016 ISSN 1412-5382 
memiliki signifikan terhadap santri lainnya.

Tabel 5: Memberi Salam Dan Menjawab Salam Ketika Berjumpa Dengan Orang

\begin{tabular}{clcc}
\hline No & Klasifikasi Jawaban & Jumlah Responden & Persentasi (\%) \\
\hline 1 & Sangat setuju & 42 & $48,837 \%$ \\
\hline 2 & Setuju & 30 & $34,884 \%$ \\
\hline 3 & Kurang setuju & 5 & $5,814 \%$ \\
\hline 4 & Tidak setuju & 5 & $5,814 \%$ \\
\hline 5 & Sangat tidak setuju & 4 & $4,651 \%$ \\
\hline & Jumlah & 86 & $100 \%$ \\
\hline
\end{tabular}

Berdasarkan tabel di atas, tergambar bahwa 42 santri Madrasah Aliyah di Pesantren Jabal Nur dari 86 responden yang diteliti atau 48,837\% santri "Sangat setuju" memberi salam dan menjawab salam ketika berjumpa dengan orang. Di samping itu ditemukan juga data dimana 30 orang santri atau jika di persentasekan sama dengan $(34,884 \%)$ yang mengisi angket "Setuju" dalam memberi salam dan menjawab salam ketika berjumpa dengan orang.

Selain itu ditemukan juga data dimana 5 orang santri Madrasah Aliyah di Pesantren Jabal Nur dari 86 respoden atau (5,814\%). Menjawab "Kurang Setuju" terindikasi memberi salam dan menjawab salam ketika berjumpa dengan orang. Bila dilihat dari tingkatan jawaban ini, berada pada tingkat ketiga dari lima tingkatan jawaban yang ditetapkan, dua tingkatan di atas nya adalah sangat setuju dan setuju. Bila dilihat jawaban ini 5 orang santri dari 86 responden, sangat terlalu memprihatinkan sebab data ini memiliki signifikan terhadap santri lain.

Di lain sisi terdapat pula data di mana ada 5 orang santri atau jika dipersentasekan sama dengan $(5,814 \%)$ mengisi angket "Tidak Setuju". Data selanjutnya ditemukan dimana 4 orang santri Madrasah Aliyah di Pesantren Jabal Nur dari 86 responden atau $(4,651 \%)$ menjawab "Sangat Tidak Setuju" terindikasi terhadap memberi salam dan menjawab salam ketika berjumpa dengan orang.

Tabel 6: Meminta Izin Dengan Orang Tua Ketika Hendak Berpergian

\begin{tabular}{clcc}
\hline No & Klasifikasi Jawaban & Jumlah Responden & Persentasi (\%) \\
\hline 1 & Sangat setuju & 55 & $63,953 \%$ \\
\hline 2 & Setuju & 15 & $17,442 \%$ \\
\hline 3 & Kurang setuju & 7 & $8,14 \%$ \\
\hline 4 & Tidak setuju & 7 & $8,14 \%$ \\
\hline 5 & Sangat tidak setuju & 2 & $2,326 \%$ \\
\hline & Jumlah & 72 & $100 \%$ \\
\hline
\end{tabular}

Berdasarkan tabel di atas, tergambar bahwa 55 santri Madrasah Aliyah di Pesantren Jabal Nur dari 86 responden yang diteliti atau 63,953\% santri "Sangat setuju" meminta izin dengan orang tua ketika hendak berpergian. Di samping itu ditemukan juga data dimana 15 orang santri Madrasah Aliyah di Pesantren Jabal Nur dari 86 responden yang mengisi angket jika di persentasekan sama dengan $(17,442 \%)$ atau "Setuju" meminta izin dengan orang tua ketika hendak berpergian. Selain itu ditemukan juga data dimana 7 orang santri Madrasah Aliyah di Pesantren Jabal Nur dari 86 respoden atau $(8,14 \%)$ menjawab "Kurang Setuju". Di lain sisi terdapat pula data di mana ada 7 orang santri Madrasah Aliyah di Pesantren Jabal Nur

Jurnal Al-hikmah Vol. 13, No. 2, Oktober 2016 ISSN 1412-5382 
atau jika dipersentasekan sama dengan $(8,14 \%)$ menjawab "Tidak Setuju".

Data selanjutnya ditemukan dimana 2 orang santri Madrasah Aliyah di Pesantren Jabal Nur dari 86 responden atau (2,326\%) menjawab "Sangat Tidak Setuju" terindikasi terhadap meminta izin dengan orang tua ketika hendak berpergian.

Tabel 7: Meminta Izin Dengan Guru Ketika Hendak Keluar Kelas

\begin{tabular}{clcc}
\hline No & Klasifikasi Jawaban & Jumlah Responden & Persentasi (\%) \\
\hline 1 & Sangat setuju & 50 & $58,14 \%$ \\
\hline 2 & Setuju & 21 & $24,419 \%$ \\
\hline 3 & Kurang setuju & 7 & $8,14 \%$ \\
\hline 4 & Tidak setuju & 7 & $8,14 \%$ \\
\hline 5 & Sangat tidak setuju & 1 & $1,163 \%$ \\
\hline & Jumlah & 86 & $100,02 \%$ \\
\hline
\end{tabular}

Berdasarkan tabel di atas, tergambar bahwa 50 santri Madrasah Aliyah di Pesantren Jabal Nur dari 86 responden yang diteliti atau 58,14\% santri "Sangat setuju" meminta izin dengan guru ketika hendak keluar kelas. Di samping itu ditemukan juga data dimana 21 orang santri atau jika di persentasekan sama dengan $(24,419 \%)$ yang mengisi angket "Setuju" untuk meminta izin dengan guru ketika hendak keluar kelas..

Selain itu ditemukan juga data dimana 7 orang santri atau $(8,14 \%)$ yang menjawab "Kurang Setuju" terindikasi meminta izin dengan guru ketika hendak keluar kelas. Di lain sisi terdapat pula data di mana ada 7 orang santri Madrasah Aliyah di Pesantren Jabal Nur atau jika dipersentasekan sama dengan $(8,14 \%)$ yang menjawab "Tidak Setuju".

Data selanjutnya ditemukan dimana 1 orang santri Madrasah Aliyah di Pesantren Jabal Nur dari 86 responden atau (1,163\%). Menjawab "Sangat Tidak Setuju" terindikasi terhadap meminta izin dengan guru ketika hendak keluar kelas.

Tabel 8: Menghormati Yang Lebih Tua Dan Menyayangi Yang Lebih Muda

\begin{tabular}{clcc}
\hline No & Klasifikasi Jawaban & Jumlah Responden & Persentasi (\%) \\
\hline 1 & Sangat setuju & 39 & $45,349 \%$ \\
\hline 2 & Setuju & 34 & $39,535 \%$ \\
\hline 3 & Kurang setuju & 7 & $8,14 \%$ \\
\hline 4 & Tidak setuju & 5 & $5,814 \%$ \\
\hline 5 & Sangat tidak setuju & 1 & $1,163 \%$ \\
\hline & Jumlah & 86 & $100 \%$ \\
\hline
\end{tabular}

Berdasarkan tabel di atas, tergambar bahwa 39 santri Madrasah Aliyah di Pesantren Jabal Nur dari 86 responden yang diteliti atau 45,349\% santri "Sangat setuju" menghormati yang lebih tua dan menyayangi yang lebih muda. Di samping itu ditemukan juga data dimana 34 orang santri Madrasah Aliyah di Pesantren Jabal Nur dari 86 responden yang mengisi angket jika di persentasekan sama dengan $(39,535 \%)$ atau "Setuju" menghormati yang lebih tua dan menyayangi yang lebih muda. Hal ini dapat dilihat dari hasil perolehan data dimana 24,419\% "Setuju" dalam menghormati yang lebih tua dan menyayangi yang lebih muda. Selain itu ditemukan juga data dimana 7 orang santri Madrasah Aliyah di Pesantren Jabal Nur dari 86 respoden atau $(8,14 \%)$. Menjawab "Kurang Setuju" 
terindikasi menghormati yang lebih tua dan menyayangi yang lebih muda.

Di lain sisi terdapat pula data di mana ada 5 orang santri Madrasah Aliyah di Pesantren Jabal Nur atau jika dipersentasekan sama dengan $(5,814 \%)$ "Tidak Setuju", terindikasi dalam menghormati yang lebih tua dan menyayangi yang lebih muda. Data selanjutnya ditemukan dimana 1 orang santri Madrasah Aliyah di Pesantren Jabal Nur dari 86 responden atau $(1,163 \%)$ yang menjawab "Sangat Tidak Setuju" terindikasi terhadap menghormati yang lebih tua dan menyayangi yang lebih muda.

Tabel 9: Bersikap Santun Dan Tidak Sombong Kepada Orang-Orang Ketika Sedang Melakukan Aktivitas

\begin{tabular}{llcc}
\hline No & Klasifikasi Jawaban & Jumlah Responden & Persentasi (\%) \\
\hline 1 & Sangat setuju & 35 & $40,698 \%$ \\
\hline 2 & Setuju & 40 & $46,512 \%$ \\
\hline 3 & Kurang setuju & 8 & $9,302 \%$ \\
\hline 4 & Tidak setuju & 2 & $2,326 \%$ \\
\hline 5 & Sangat tidak setuju & 1 & $1,163 \%$ \\
\hline & Jumlah & 86 & $100 \%$ \\
\hline
\end{tabular}

Berdasarkan tabel di atas, tergambar bahwa 35 santri Madrasah Aliyah di Pesantren Jabal Nur dari 86 responden yang diteliti atau 40,698\% santri "Sangat setuju" bersikap santun dan tidak sombong kepada orang-orang ketika sedang melakukan aktivitas. Di samping itu ditemukan juga data dimana 40 orang santri Madrasah Aliyah di Pesantren Jabal Nur dari 86 responden yang mengisi angket jika di persentasekan sama dengan (46,512\%) atau "Setuju" bersikap santun dan tidak sombong kepada orang-orang ketika sedang melakukan aktivitas.

Selain itu ditemukan juga data dimana 8 orang santri Madrasah Aliyah di Pesantren Jabal Nur dari 86 respoden atau $(9,302 \%)$ yang menjawab "Kurang
Setuju" terindikasi bersikap santun dan tidak sombong kepada orang-orang ketika sedang melakukan aktivitas. Di lain sisi terdapat pula data di mana ada 2 orang santri Madrasah Aliyah di Pesantren Jabal Nur atau jika dipersentasekan sama dengan (2,326\%) "Tidak Setuju", terindikasi dalam bersikap santun dan tidak sombong kepada orang-orang ketika sedang melakukan aktivitas

Data selanjutnya ditemukan dimana 1 orang santri Madrasah Aliyah di Pesantren Jabal Nur dari 86 responden atau (1,163\%). Menjawab "Sangat Tidak Setuju" terindikasi terhadap bersikap santun dan tidak sombong kepada orang-orang ketika sedang melakukan aktivitas.

Tabel 10: Berbicara Dengan Perkaataan Yang Sopan Terhadap Orang

\begin{tabular}{llcc}
\hline No & Klasifikasi Jawaban & Jumlah Responden & Persentasi (\%) \\
\hline 1 & Sangat setuju & 37 & $43,023 \%$ \\
\hline 2 & Setuju & 35 & $40,698 \%$ \\
\hline 3 & Kurang setuju & 7 & $8,14 \%$ \\
\hline 4 & Tidak setuju & 6 & $6,977 \%$ \\
\hline 5 & Sangat tidak setuju & 1 & $1,163 \%$ \\
\hline & Jumlah & 86 & $100 \%$ \\
\hline
\end{tabular}

Berdasarkan tabel di atas, tergambar bahwa 37 santri Madrasah

Aliyah di Pesantren Jabal Nur dari 86 Jurnal Al-hikmah Vol. 13, No. 2 
santri "Sangat setuju" berbicara dengan perkataan yang sopan terhadap orang. Di samping itu ditemukan juga data dimana 35 orang santri Madrasah Aliyah di Pesantren Jabal Nur dari 86 responden yang mengisi angket jika di persentasekan sama dengan (40,698\%) atau "Setuju" berbicara dengan perkataan yang sopan terhadap orang.

Selain itu ditemukan juga data dimana 7 orang santri Madrasah Aliyah di Pesantren Jabal Nur dari 86 respoden atau (8,14\%). Menjawab "Kurang Setuju" terindikasi berbicara dengan perkataan yang sopan terhadap orang. Di lain sisi terdapat pula data di mana ada 6 orang santri Madrasah Aliyah di Pesantren Jabal Nur atau jika dipersentasekan sama dengan $(6,977 \%)$ "Tidak Setuju", terindikasi dalam berbicara dengan perkataan yang sopan terhadap orang.

Data selanjutnya ditemukan dimana 1 orang santri Madrasah Aliyah di Pesantren Jabal Nur dari 86 responden atau $(1,163 \%)$. Menjawab "Sangat Tidak Setuju" terindikasi terhadap berbicara dengan perkataan yang sopan terhadap orang.

Tabel 11: Tidak Suka Menghina Siapa Pun

\begin{tabular}{llcc}
\hline No & Klasifikasi Jawaban & Jumlah Responden & Persentasi (\%) \\
\hline 1 & Sangat setuju & 34 & $39,535 \%$ \\
\hline 2 & Setuju & 40 & $46,512 \%$ \\
\hline 3 & Kurang setuju & 7 & $8,14 \%$ \\
\hline 4 & Tidak setuju & 3 & $3,488 \%$ \\
\hline 5 & Sangat tidak setuju & 2 & $2,326 \%$ \\
\hline & Jumlah & 86 & $100 \%$ \\
\hline
\end{tabular}

Berdasarkan tabel di atas, tergambar bahwa 34 santri Madrasah Aliyah di Pesantren Jabal Nur dari 86 responden yang diteliti atau 39,535\% santri "Sangat setuju" tidak suka menghina siapa pun. Di samping itu ditemukan juga data dimana 40 orang santri Madrasah Aliyah di Pesantren Jabal Nur dari 86 responden yang mengisi angket jika di persentasekan sama dengan $(46,512 \%)$ atau "Setuju" tidak suka menghina siapa pun. Selain itu ditemukan juga data dimana 7 orang santri Madrasah Aliyah di Pesantren Jabal Nur dari 86 respoden atau
(8,14\%). Menjawab "Kurang Setuju" terindikasi tidak suka menghina siapa pun.

Di lain sisi terdapat pula data di mana ada 3 orang santri Madrasah Aliyah di Pesantren Jabal Nur atau jika dipersentasekan sama dengan $(6,977 \%)$ "Tidak Setuju", terindikasi dalam tidak suka menghina siapa pun. Data selanjutnya ditemukan dimana 2 orang santri Madrasah Aliyah di Pesantren Jabal Nur dari 86 responden atau (2,326\%). Menjawab "Sangat Tidak Setuju" terindikasi terhadap tidak suka menghina siapa pun.

Tabel 12: Tidak Suka Membenci Dan Iri Dengan Siapa Pun

\begin{tabular}{llcc}
\hline No & Klasifikasi Jawaban & Jumlah Responden & Persentasi (\%) \\
\hline 1 & Sangat setuju & 33 & $38,372 \%$ \\
\hline 2 & Setuju & 41 & $47,674 \%$ \\
\hline 3 & Kurang setuju & 7 & $8,14 \%$ \\
\hline 4 & Tidak setuju & 3 & $3,488 \%$ \\
\hline 5 & Sangat tidak setuju & 2 & $2,326 \%$ \\
\hline & Jumlah & 86 & $100 \%$ \\
\hline
\end{tabular}


Berdasarkan tabel di atas, tergambar bahwa 33 santri Madrasah Aliyah di Pesantren Jabal Nur dari 86 responden yang diteliti atau 38,372\% santri "Sangat setuju" tidak suka membenci dan iri dengan siapa pun. Di samping itu ditemukan juga data dimana 41 orang santri Madrasah Aliyah di Pesantren Jabal Nur dari 86 responden yang mengisi angket jika di persentasekan sama dengan $(47,674 \%)$ atau "Setuju" tidak suka membenci dan iri dengan siapa pun. Selain itu ditemukan juga data dimana 7 orang santri Madrasah Aliyah di Pesantren Jabal Nur dari 86 respoden atau
(8,14\%). Menjawab "Kurang Setuju" terindikasi tidak suka membenci dan iri dengan siapa pun.

Di lain sisi terdapat pula data di mana ada 3 orang santri Madrasah Aliyah di Pesantren Jabal Nur atau jika dipersentasekan sama dengan $(6,977 \%)$ "Tidak Setuju", terindikasi dalam tidak suka membenci dan iri dengan siapa pun. Data selanjutnya ditemukan dimana 2 orang santri Madrasah Aliyah di Pesantren Jabal Nur dari 86 responden atau (2,326\%). Menjawab "Sangat Tidak Setuju" terindikasi terhadap tidak suka membenci dan iri dengan siapa pun.

Tabel 13: Suka Mengisi Waktu Luang Dengan Kegiatan Yang Bermanfaat

\begin{tabular}{llcc}
\hline No & Klasifikasi Jawaban & Jumlah Responden & Persentasi (\%) \\
\hline 1 & Sangat setuju & 42 & $48,837 \%$ \\
\hline 2 & Setuju & 28 & $32,558 \%$ \\
\hline 3 & Kurang setuju & 7 & $8,14 \%$ \\
\hline 4 & Tidak setuju & 7 & $8,14 \%$ \\
\hline 5 & Sangat tidak setuju & 2 & $2,326 \%$ \\
\hline & Jumlah & 86 & $100 \%$ \\
\hline
\end{tabular}

Berdasarkan tabel di atas, tergambar bahwa 42 santri Madrasah Aliyah di Pesantren Jabal Nur dari 86 responden yang diteliti atau 48,83\% santri "Sangat setuju" suka mengisi waktu luang dengan kegiatan yang bermanfaat. Di samping itu ditemukan juga data dimana 28 orang santri dari 86 responden yang mengisi angket jika di persentasekan sama dengan $(32,558 \%)$ atau "Setuju" suka mengisi waktu luang dengan kegiatan yang bermanfaat.

Selain itu ditemukan juga data dimana 7 orang santri Madrasah Aliyah di Pesantren Jabal Nur dari 86 respoden atau (8,14\%). Menjawab "Kurang Setuju" terindikasi suka mengisi waktu luang dengan kegiatan yang bermanfaat. Di lain sisi terdapat pula data di mana ada 7 orang santri Madrasah Aliyah di Pesantren Jabal Nur atau jika dipersentasekan sama dengan $(8,14 \%)$ "Tidak Setuju", terindikasi dalam suka mengisi waktu luang dengan kegiatan yang bermanfaat.

Data selanjutnya ditemukan dimana 2 orang santri Madrasah Aliyah di Pesantren Jabal Nur dari 86 responden atau $(2,326 \%)$ menjawab "Sangat Tidak Setuju" terindikasi terhadap suka mengisi waktu luang dengan kegiatan yang bermanfaat.

Tabel14: Suka Mengajak Teman Untuk Berbuat Kebajikan

\begin{tabular}{llcc}
\hline No & Klasifikasi Jawaban & Jumlah Responden & Persentasi (\%) \\
\hline 1 & Sangat setuju & 44 & $51,163 \%$ \\
\hline 2 & Setuju & 28 & $32,558 \%$ \\
\hline 3 & Kurang setuju & 8 & $9,302 \%$ \\
\hline 4 & Tidak setuju & 4 & $4,651 \%$ \\
\hline
\end{tabular}

Jurnal Al-hikmah Vol. 13, No. 2, Oktober 2016 ISSN 1412-5382 


\begin{tabular}{clcc}
\hline 5 & Sangat tidak setuju & 2 & $2,326 \%$ \\
\hline & Jumlah & 86 & $100 \%$ \\
\hline
\end{tabular}

Berdasarkan tabel di atas, tergambar bahwa 44 santri Madrasah Aliyah di Pesantren Jabal Nur dari 86 responden yang diteliti atau 51,163\% santri "Sangat setuju" suka mengajak teman untuk berbuat kebajikan. Di samping itu ditemukan juga data dimana 28 orang santri Madrasah Aliyah di Pesantren Jabal Nur dari 86 responden yang mengisi angket jika di persentasekan sama dengan $(32,558 \%)$ atau "Setuju" suka mengajak teman untuk berbuat kebajikan.

Selain itu ditemukan juga data dimana 8 orang santri Madrasah Aliyah di Pesantren Jabal Nur dari 86 respoden atau (9,302\%). Menjawab "Kurang Setuju" terindikasi suka mengajak teman untuk berbuat kebajikan. Di lain sisi terdapat pula data di mana ada 4 orang santri Madrasah Aliyah di Pesantren Jabal Nur atau jika dipersentasekan sama dengan $(8,14 \%)$ "Tidak Setuju", terindikasi dalam suka mengajak teman untuk berbuat kebajikan. Bila dilihat dari tingkatan jawaban ini, berada pada tingkat keempat dari lima tingkatan yang ditetapkan, tiga tingkatan di atasnya adalah sangat setuju, setuju, dan kurang setuju.

Data selanjutnya ditemukan dimana 2 orang santri Madrasah Aliyah di Pesantren Jabal Nur dari 86 responden atau (2,326\%). Menjawab "Sangat Tidak Setuju" terindikasi terhadap suka mengajak teman untuk berbuat kebajikan.

Berdasarkan rekapitulasi dari hasil angket yang disebarkan kepada 86 responden diperoleh jumlah frekuensi jawaban "Sangat Setuju" sebanyak 536 responden dengan presentase 47,94\% frekuensi yang "Setuju" sebanyak 402 responden dengan presentase 35,96\% frekuensi jawaban "Kurang Setuju" 90 responden dengan presentase 8,05\% frekuensi jawaban "Tidak Setuju" 67 responden dengan presentase 5,99\% frekuensi jawaban "Sangat Tidak Setuju" 23 responden dengan presentase 2,06\%.

Untuk memberikan penilaian maka setiap option diberikan skor sebagai berikut: (a) Untuk alternatif SS diberikan skor 5; (b) Untuk alternatif S diberikan skor 4; (c) Untuk alternatif KS diberikan skor 3; (d) Untuk alternatif TS diberikan skor 2; dan (e) Untuk alternatif STS diberikan skor 1 .

Berdasarkan skor tersebut dapat dinilai secara keseluruhan hasil rekapitulasi dan jumlah skor ideal tertinggi untuk keseluruhan item tentang Etika Pergaulan Islami Santri Madrasah Aliyah (MA) di Pesantren Jabal Nur Kecamatan Kandis Kabupaten Siak. Alternatif jawaban SS: $536 \times 5=2,680$ Alternatif jawaban S : $402 \times 4=1,608$ Alternatif jawaban KS: $90 \times 3=270$ Alternatif jawaban TS: $67 \times 2=134$ Alternatif jawaban STS: $23 \times 1=23$ Jumlah total $\quad 1,118=4.715$

$5 \times 1,118=5,59=$ nilai ideal

$$
\begin{aligned}
& N=5,59 \\
& F=\frac{4.715}{5,59} \times 100 \%=
\end{aligned}
$$

$84.35 \%$

Berdasarkan hasil rekapitulasi angket dari uraian di atas dapat diambil kesimpulan bahwa Etika Pergaulan Islami Santri Madrasah Aliyah (MA) di Pesantren Jabal Nur Kecamatan Kandis Kabupaten Siak adalah $84,35 \%$ hal ini menggambarkan kategori baik, atau pada rentang $81-100 \%$.

Hasil analisa ini membuktikan bahwa asumsi awal tentang Etika Pergaulan Islami Santri Madrasah Aliyah (MA) Di Pesantren Jabal Nur Kecamatan Kandis Kabupaten Siak, justru memberikan pembuktian bahwa Etika Pergaulan Islami Santri Di Pesantren 
Jabal Nur Kecamatan Kandis Kabupaten Siak pada kategori baik.

\section{SIMPULAN}

Etika bergaul Islami sangat penting bagi remaja saat ini, karena dengan adanya etika maka akan terbentuk, akhlaqul karimah yang baik didalam diri anak tersebut. Jika santri mendapat pendidikan etika yang lebih banyak lagi maka santri tersebut bisa membedakan mana yang baik dan buruk dalam memilih pergaulan dalam bersosial. Oleh karena itu etika pergaulan remaja saat ini harus di perhatikan, agar remaja tidak terperosok dalam pergaulan yang tidak baik, seperti berbohong, saling membenci, memakai narkoba, berjudi, mencuri, didalam kehidupan remaja.

Berdasarkan hasil penelitian tentang etika bergaul islami antara santri Madrasah Aliyah (MA) di Pesantren Jabal Nur Kecamatan Kandis Kabupaten Siak dapat disimpulkan bahwa Etika Pergaulan Islami Santri Madrasah Aliyah (MA) di Pesantren Jabal Nur Kecamatan Kandis Kabupaten Siak 84,35\% atau berada pada rentang 81-100\% menggambarkan kategori "baik".

\section{DAFTAR RUJUKAN}

Muhammad, Abu Bakar. 1994. Pembinaan Manusia Dalam Islam. Surabaya: Al Ikhlas.

Andi Aniran dan Sitti Hasnah, "Pendidikan Islam dan Etika Pergaulan Remaja (Studi pada Peserta Didik MAN 2 Palu)", Jurnal
Penelitian Istiqra', Palu, Vol. 1, No.2 Juli-Desember 2013.

Abdullah Idi dan Safarina HD. Sosiologi PendidikanIindividu, Masyarakat, dan Pendidikan. Jakarta: RajaGrafindo Persada, 2011.

Abuddin Nata. Akhlak tasawuf. Jakarta: RajaGrafindo Persada, 1996.

Burhanuddin Salam. Etika Individual Pola Dasar Filsafat Moral. Jakarta: Rineka Cipta, 2000.

Didiek Ahmad Supadie dan Sarjunu. Pengantar Study Islam. Jakarta: RajaGrafindo, 2012.

Faizal Badroen, dkk. Etika Bisnis Dalam Islam. Jakarta: Rawamangun, 2007.

Hasbullah. Dasar-Dasar Ilmu Pendidikan. Jakarta: RajaGrafindo Persada, 2009.

Imam Gunawan, Metode Penelitian Kualitatif. Jakarta: Bumi Aksara, 2014.

Ismatu Ropi, dkk. Pendidikan Agama Islam. Jakarta: Rawamangun, 2012.

Mohammad Ali dan Mohammad Asrori. Psikologi Remaja. Jakarta: PT Bumi Aksara, 2012.

Novan Ardy Wiyani \& Barnawi. Ilmu Pendidikan Islam. Jogjakarta: ArRuzz Media, 2012.

Sugiono. Metode Penelitian. Bandung: Alfabet, 1999

Suharsimi Arikunto. Metode Penelitian. Jakarta: RajaGrafindo Persada, 2013

Syamsu Yusuf. Psikologi Perkembangan Anak \& Remaja. Bandung: Remaja Rosdakarya Offset, 2007.

Yunahar Ilyas. Kuliah Akhlak. Yogyakarta: Pustaka Pelajar Offset, 2002. Zaprulkhan. Filsafat Umum. Jakarta: Rajagrafindo Persada, 2013. 